\title{
ANALISIS KEMAMPUAN PEMAHAMAN KONSEP MATEMATIKA SISWA BERBANTUAN MEDIA SCHOOLOGY
}

\author{
Lia Yulianah ${ }^{1}$, Khomsatun Ni'mah $^{2}$, Diar Veni Rahayu ${ }^{3)}$ \\ ${ }^{1}$ Mahasiswa Prodi Magister Pendidikan Matematika, Universitas Siliwangi \\ 1Email: liayulianah406@gmail.com \\ ${ }^{2,3}$ Dosen Prodi Magister Pendidikan Matematika, Universitas Siliwangi \\ 2Email: khomsatunnimah@unsil.ac.id \\ ${ }^{3}$ Email: diarvenirahayu@unsil.ac.id
}

\begin{abstract}
Abstrak
Tujuan penelitian ini yaitu untuk menganalisis kemampuan pemahaman konsep matematika siswa dalam menyelesaikan masalah bangun ruang sisi datar kubus dan balok dengan berbantuan media Schoology. Metode penelitian ini menggunakan metode kualitatif dengan pendekatan deskriptif. Penelitian ini mendeskripsikan kemampuan pemahaman konsep matematika yang dimiliki siswa dengan berbantuan media Schoology. Subjek penelitian sebanyak tiga siswa yang dipilih secara purposive sampling berdasarkan pertimbangan kondisi dan situasi yang terjadi saat pandemi covid19 saat ini. Pengumpulan data yang digunakan berupa tes kemampuan pemahaman konsep matematika. Berdasarkan hasil penelitian menunjukkan bahwa kemampuan pemahaman konsep matematika siswa dengan berbantuan Schoology mampu memberikan pemahaman yang lebih terhadap materi bangun ruang sisi datar kubus dan balok dengan ditunjukkannya hasil rata-rata siswa memperoleh nilai 91,67. Dimana siswa pertama mampu mencapai kelima indikator pemahaman konsep matematika dari kelima indikator yang diberikan yaitu dengan mampu menyatakan ulang sebuah konsep, mengklasifikasikan objek-objek menurut sifat-sifat tertentu, menyajikan konsep dalam berbagai bentuk representasi matematis, menjelaskan keterkaitan antara konsep satu dengan konsep lainnya, dan menerapkan konsep dalam pemecahan masalah. Sedangkan siswa kedua dan ketiga hanya dapat mencapai empat indikator dari kelima indikator pemahaman konsep matematika yang diberikan. Namun demikian, siswa menunjukkan respon positif terhadap media Schoology.
\end{abstract}

Kata Kunci: Pemahaman Konsep Matematika, Media Schoology

\begin{abstract}
The purpose of this study was to examine the mathematical concepts of students in solving the problem of polyhedron of cubes and cuboids with assisted of Schoology media. This research uses qualitative methods with descriptive approach. This study describes the ability to understand mathematical concepts that owned of students with Schoology media. Research subjects is three students selected by purposive sampling based on conditions and situations that occured during the current co-19 pandemic. The data collection used consists of tests of understanding the ability of mathematical concepts. Based on the results of research showed that the ability to understanding students' of mathematical concepts with Schoology-assisted able to provide understanding of material polyhedron of cubes and cuboids by the average results of students getting value 91,67. Where the first student is able to reach an understanding indicator of mathematical concepts from given by agreeing to the concept, classifying objects according to certain properties, giving concepts in various forms of mathematical representation, explaining the relationship between one concept with another concept, and applying the concept in problem solving. While the second and third students can only reach four indicators from the second indicator given. Nevertheless, students show positive responses to Schoology media.
\end{abstract}

Keywords: Understanding Mathematical Concepts, Schoology Media 
Analisis Kemampuan Pemahaman Konsep Matematika Siswa Berbantuan Media Schoology

Lia Yulianah ${ }^{1)}$, Khomsatun Ni'mah' ${ }^{2)}$, Diar Veni Rahayu ${ }^{3)}$

\section{PENDAHULUAN}

Sagala (2003: 71) mengungkapkan bahwa konsep merupakan buah pemikiran seseorang atau sekelompok orang yang dinyatakan dalam definisi sehingga melahirkan produk pengetahuan meliputi prinsip, hukum, dan teori. Konsep diperoleh dari fakta, peristiwa, pengalaman, melalui generalisasi dan berfikir abstrak. Konsep dapat mengalami perubahan disesuaikan dengan fakta atau pengetahuan baru, sedangkan kegunaan konsep untuk menjelaskan dan meramalkan. Duffin dan Simpson dalam bukunya Kesumawati (2008: 230) menyatakan bahwa pemahaman konsep sebagai kemampuan siswa untuk: (1) menjelaskan konsep, dapat diartikan siswa mampu untuk mengungkapkan kembali apa yang telah dikomunikasikan kepadanya, (2) menggunakan konsep pada berbagai situasi yang berbeda, dan (3) mengembangkan beberapa akibat dari adanya suatu konsep. Dengan kata lain, dengan pemahaman yang dimiliki siswa terhadap suatu konsep mengakibatkan siswa mempunyai kemampuan untuk dapat menyelesaikan setiap permasalahan matematika yang diberikan dengan benar.

Berdasarkan penjelasan tersebut, maka dapat disimpulkan bahwa pemahaman konsep merupakan kemampuan siswa dalam menjelaskan konsep yang telah dipahaminya dan mampu menerapakan konsep tersebut dalam situasi berbeda, serta dengan pemahaman konsep yang dimiliki siswa mampu untuk mengembangkan konsep tersebut dalam menyelesaikan masalah matematika. Menurut Heruman (Karim, A. 2011: 30) dalam matematika setiap konsep berkaitan dengan konsep lain, dan suatu konsep menjadi prasyarat bagi konsep lainnya. Oleh sebab itu, pemahaman konsep merupakan hal yang sangat fundamental dalam pembelajaran matematika agar lebih bermakna. Artinya pemahaman konsep memiliki peranan yang sangat penting yang harus di miliki oleh siswa agar pembelajaran yang dilakukan memiliki kebermaknaan yang berarti.

Bukan hal yang tabu lagi jika siswa menganggap bahwa pelajaran matematika merupakan pelajaran yang sukar, rumit, menakutkan, membosankan. Seperti yang diungkapkan Marti dalam bukunya Sundayana, R.(2014: 3) menyatakan bahwa obyek matematika yang bersifat abstrak tersebut merupakan kesulitan tersendiri yang harus dihadapi siswa dalam mempelajari matematika. Oleh karena itu, peserta didik menganggap pelajaran matematika merupakan pelajaran yang rumit dan susah. Hal tersebut dapat diartikan bahwa kemampuan pemahaman konsep matematika siswa masih tergolong rendah dan belum berkembang dengan baik. Hal tersebut juga yang menyebabkan siswa merasa kesulitan dalam mempelajari pelajaran matematika. Sehingga, mereka menganggap matematika merupakan pelajaran yang sangat sulit dan cenderung membosankan.

Beberapa faktor yang menyebabkan matematika dianggap pelajaran yang sulit, diantaranya yaitu karakteristik materi matematika yang bersifat abstrak, logis, sistematis dan penuh dengan lambang-lambang dan rumus-rumus. Kesulitan siswa dalam menghadapi penyelesaiaan soal-soal matematika menunjukan bahwa kemampuan pemahaman konsep siswa terhadap materi yang diberikan masih tergolong rendah. Hal tersebut mengakibatkan mereka merasa keberatan dan enggan untuk mengerjakan soal-soal matematika yang diberikan. Hal tersebut juga yang mengakibatkan rendahnya motivasi siswa dalam proses pembelajaran matematika.

Adapun indikator dari pemahaman konsep matematika menurut kurikulum 2006 diantaranya yaitu agar siswa dapat menyatakan ulang sebuh konsep, mengklasifikasi objek-objek menurut sifat-sifat tertentu (sesuai dengan konsepnya), menjelaskan dan menginterpretasikan hasil jawaban, memberikan contoh dan non-contoh dari konsep, menyajikan konsep dalam berbagai bentuk representasi matematis, dan mengaplikasikan konsep atau algoritma dalam pemecahan masalah.

Disamping beberapa hal yang telah dikemukakan diatas, Kesulitan yang dihadapi siswa juga dikarenakan metode yang digunakan dalam pembelajaran cenderung monoton yang difokuskan atau terpusatnya pembelajaran pada pendidik, tidak variatifnya pembelajaran yang dilakukan juga mempengaruhi peserta didik dalam memahami konsep dari materi yang diberikan. Pembelajaran 
yang dilakukan dikelas menimbulkan kejenuhan tersendiri bagi peserta didik. Oleh karena itu, penggunaan media pembelajaran e-learning merupakan salah satu alternatif yang dapat digunakan dan dilakukan untuk memperoleh pembelajaran yang bermakna.

Menurut Stockley (2006) E-Learning sebagai penyampaian program pembelajaran, pelatihan, atau pendidikan dengan menggunakan sarana atau alat elektronik seperti komputer atau alat elektronik lain seperti telepon genggam dengan berbagai cara untuk memberikan pelatihan, pendidikan, atau bahan ajar. Melalui e-Learning ini maka pendidik dan peserta didik dapat melakukan pembelajaran kapan saja dan dimana saja asalkan didukung dengan tetap terkoneksinya media tersebut dengan jaringan internet.

Beberapa manfaat e-Learning dalam kegiatan pembelajaran menurut Siahaan (2003) yaitu sebagai suplemen (tambahan), sebagai komplemen (pelengkap), dan sebagai substitusi (pengganti). Manfaat e-Learning sebagai suplemen (tambahan) yaitu peserta didik mempunyai kebebasan memilih, apakah akan memanfaatkan materi melalui $e$ Learning atau tidak. Manfaat e-Learning sebagai komplemen (pelengkap) yaitu materinya diprogramkan untuk melengkapi materi pembelajaran yang diterima peserta didik di dalam kelas. Sedangkan manfaat e-Learning sebagai substitusi (pengganti) peserta didik sepenuhnya melakukan tatap muka dengan pendidik melalui daring.

Schoology menurut Aminoto dan Pathoni (2014) merupakan website yang memadukan e-Learning dan jejaring sosial. Penggunaan e-learning berbasis schoology mendapat respon yang baik dari siswa pada setiap aspek keseluruhan schoology karena schoology termasuk dalam kategori sangat menarik untuk pembelajaran (K. Murni dan R. Harimurti: 2016). Schoology juga dapat memberikan pengaruh terhadap nilai siswa menjadi meningkat (R. A. Sukamto: 2014). Disamping itu, dengan Schoology siswa dapat lebih memahami pelajaran serta lebih aktif dalam kegiatan pembelajaran. Sehingga menyebabkan siswa menjadi lebih semangat dan senang dalam melakukan pembelajaran serta siswa dapat belajar dimanapun (Widiantoro: 2015).

Berdasarkan uraian di atas, maka dapat disimpulkan bahwa pembelajaran yang dilakukan dengan menggunakan e-learning berbasis media Schoology dapat menumbuhkan semangat belajar siswa dan kemampuan siswa dalam memahami materi lebih mendalam yang berimplikasi terhadap meningkatnya hasil belajar. Dengan kata lain, media Schoology dapat membantu siswa untuk memiliki pemahaman konsep terhadap materi matematika yang telah diberikan, sehingga siswa dapat memecahkan permasalahan yang telah diberikan dengan baik.

Tujuan dari penelitian ini adalah untuk mengetahui dan menganalisis kemampuam pemahaman konsep matematika siswa dalam menyelesaiakan soal pemahaman konsep matematika bangun ruang sisi datar kubus dan balok berbantuan media Schoology.

\section{METODE PENELITIAN}

Penelitian yang dilakukan merupakan penelitian kualitatif dengan menggunakan metode studi kasus. Dengan metode studi kasus ini, peneliti memperoleh data primer dari informan, yang kemudian diambil kesimpulan dari data tersebut. Subjek dalam penelitian ini yaitu peserta didik yang duduk dibangku SMP kelas VIII di Lingkungan Desa Cihideunghilir kecamatan Cidahu Kabupaten Kuningan dengan jumlah siswa sebanyak 3 orang. Hal tersebut dikarenakan hanya terdapat tiga siswa yang masih duduk dibangku sekolah menengah pertama (SMP) yang ada di sekitar Lingkungan Desa Cihideunghilir.

Teknik pengambilan sampel yang dilakukan yaitu dengan mengunakan purposive sampling yang merupakan salah satu jenis probability sampling. Sugiyono (2015: 124) mengungkapkan bahwa purposive sampling merupakan teknik penentuan sampel dengan pertimbangan tertentu. Pengambilan teknik ini karena berdasarkan pertimbangan dari situasi dan kondisi pandemi covid-19 saat ini.

Pengumpulan data dalam penelitian ini yaitu menggunakan instrumen tes. Menurut Suharsimi (2011:53) Tes merupakan alat atau prosedur yang digunakan untuk mengetahui 

Schoology

Lia Yulianah ${ }^{1)}$, Khomsatun Ni'mah ${ }^{2}$, Diar Veni Rahayu ${ }^{3)}$

atau mengukur sesuatu dalam suasana, dengan cara dan aturan-aturan yang sudah ditentukan. Sehingga, dengan instrumen yang digunakan dapat mengukur kemampuan pemahaman konsep matematika siswa.

Adapun instrumen yang digunakan yaitu instrumen tes dalam bentuk pilihan ganda dan uraian (essay). Instrumen tes yang digunakan untuk menganalisis kemampuan pemahaman konsep matematika siswa terhadap materi bangun ruang sisi datar kubus dan balok. Dengan demikian, instrumen tes yang digunakan dapat menggambarkan dan mendeskripsikan kemampuan pemahaman konsep matematika yang dimiliki siswa tehadap materi bangun ruang sisi datar kubus dan balok.

Analisis data yang dilakukan yaitu setelah informan menyelesaikan soa-soal pemahaman konsep matematika yang ada dalam media Schoology. Analisis data yang dilakukan pada penelitian ini yaitu analisis terhadap data tes pilihan ganda dan essay.

\section{HASIL DAN PEMBAHASAN}

Tes kemampuan pemahaman konsep matematika diberikan untuk mengukur sejauh mana pemahaman siswa terhadap materi yang disajikan dengan bantuan media pembelajaran Schoology. Tes dilaksanakan secara daring, dan terdapat 5 soal yang diujikan setelah siswa melaksanakan pembelajaran menggunakan media pembelajaran Schoology.

Kelima soal terdiri dari 3 pilihan ganda dengan masing-masing bernilai 2 poin, dan 2 soal uraian dengan masing-masing diberi nilai 5 poin. Untuk lebih jelasnya dapat ditunjukkan pada gambar berikut:

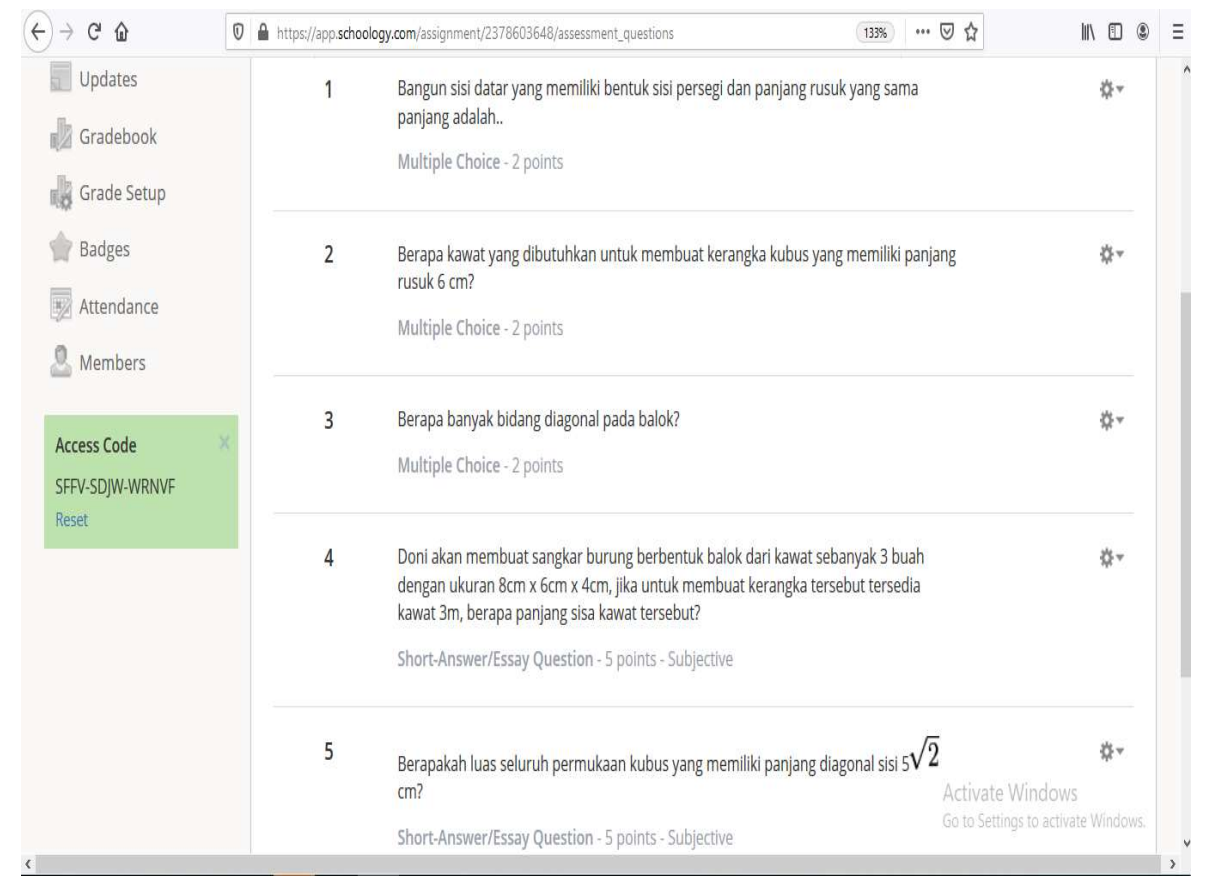

Gambar 3.1 Soal dan Skor Pemahaman Konsep Matematika

Karena pembelajaran dan pengerjaan soal dilakukan secara online, ada siswa yang mengeluhkan terkait terkendalanya sinyal. Hal ini dikarenakan dalam penggunaan media Schoology membutuhkan jaringan internet yang stabil.

Hal tersebut dapat diatasi karena tidak adanya pembatasan waktu yang diberikan dalam menyelesaikan soal namun tetap satu kali submit, artinya ketika siswa terkendala dengan jaringan atau ketika dalam proses pengerjaannya menggunakan laptop/komputer 
terjadi ketidakstabilan jaringan dan adanya pemadaman listrik secara tiba-tiba, maka siswa tidak perlu mengulang dalam menjawab soal tersebut dikarenakan hasil pengerjaan soal terakhir tersimpan secara otomatis, dan ketika jaringan internet sudah stabil siswa dapat melanjutkankanya kembali untuk menyelesaikan pengerjaan soal yang diberikan. Dengan catatan bahwa siswa belum melakukan submit terhadap hasil pengerjaannya. berikut:

Adapun hasil akhir dari pengerjaan soal yang dilakukan siswa terdapat dalam gambar

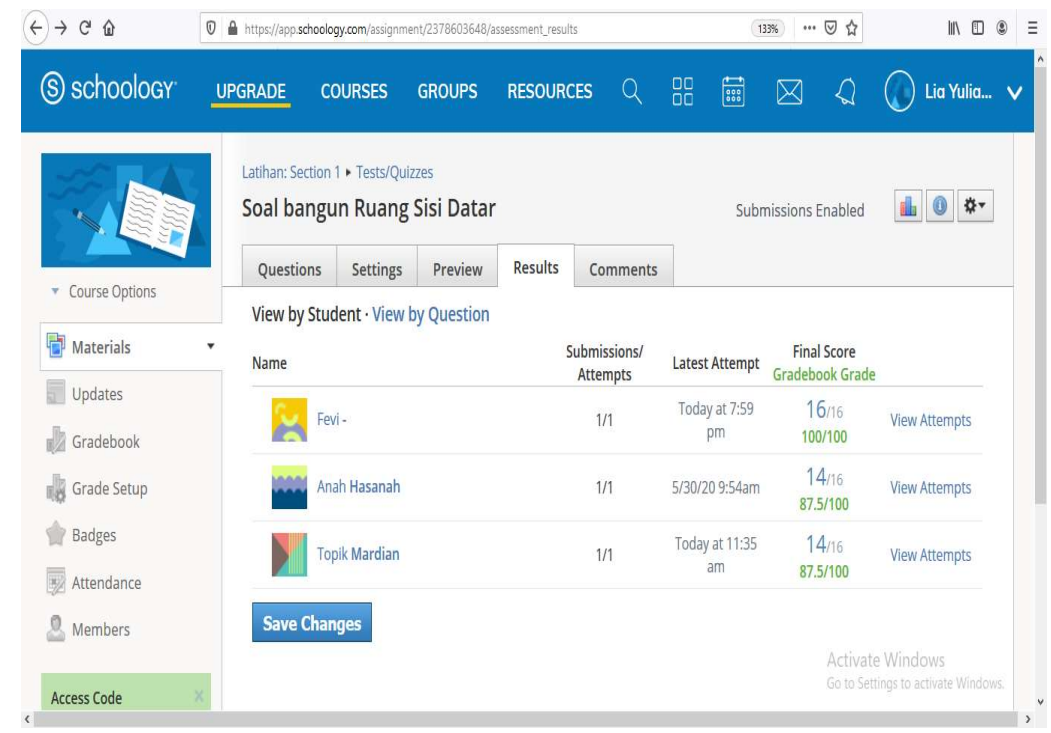

Gambar 3.2 Final Score Siswa

Ketercapaian kemampuan pemahaman konsep matematika siswa ditunjukkan dengan hasil tes yang telah dilakukan yaitu dari siswa pertama diperoleh nilai 100 dengan tercapainya kelima indikator pemahaman konsep matematika yang diberikan yaitu dengan mampu menyatakan ulang sebuah konsep, mengklasifikasikan objek-objek menurut sifatsifat tertentu, menyajikan konsep dalam berbagai bentuk representasi matematis, menjelaskan keterkaitan antara konsep satu dengan konsep lainnya, dan menerapkan konsep dalam pemecahan masalah.

Siswa kedua memperoleh nilai 87,5 dikarenakan siswa kedua tidak teliti dalam membaca soal sehingga terkecoh dalam menjawabnya. Serta siswa ketiga juga memperoleh nilai 87,5 dengan kesalahan yang sama yang terjadi pada siswa kedua dalam menjawab bidang diagonal pada balok. Dengan kata lain, karena siswa kedua dan ketiga memiliki letak kekeliruan yang sama dalam menjawab soal yang diberikan yang berkaitan dengan indikator menyatakan ulang sebuah konsep, maka siswa kedua dan ketiga hanya dapat mencapai empat indikator pemahaman konsep matematika dari lima indikator pemahamann konsep matematika yang diberikan yaitu dengan mampu mengklasifikasikan objek-objek menurut sifat-sifat tertentu, menyajikan konsep dalam berbagai bentuk representasi matematis, menjelaskan keterkaitan antara konsep satu dengan konsep lainnya, dan menerapkan konsep dalam pemecahan masalah. Namun, berdasarkan hasil final score diperoleh nilai rata-rata sebesar 91,67 dari 3 siswa. Hal tersebut menunjukkan bahwa siswa dapat memahami konsep materi bangun ruang sisi datar kubus dan balok dengan sangat baik.

Menurut Duffin dan Simpson dalam bukunya Kesumawati, N.(2008: 230), pemahaman konsep sebagai kemampuan siswa untuk: (1) menjelaskan konsep, dapat diartikan siswa mampu untuk mengungkapkan kembali apa yang telah dikomunikasikan kepadanya, (2) menggunakan konsep pada berbagai situasi yang berbeda, dan (3) mengembangkan beberapa akibat dari adanya suatu konsep, dapat diartikan bahwa siswa 
paham terhadap suatu konsep akibatnya siswa mempunyai kemampuan untuk menyelesaikan setiap masalah dengan benar.

Adapun indikator pemahaman konsep menurut Kurikulum 2006 (Kesumawati, N.2008: 234), yaitu:

a. Menyatakan ulang sebuah konsep.

b. Mengklasifikasi objek-objek menurut sifat-sifat tertentu (sesuai dengan konsepnya).

c. Memberikan contoh dan non-contoh dari konsep.

d. Menyajikan konsep dalam berbagai bentuk representasi matematis.

e. Mengembangkan syarat perlu atau syarat cukup suatu konsep.

f. Menggunakan, memanfaatkan, dan memilih prosedur atau operasi tertentu.

g. Mengaplikasikan konsep atau algoritma dalam pemecahan masalah.

Dengan kata lain, ketika siswa mampu menyelesaikan permasalahan yang diberikan dengan baik, maka siswa tersebut telah paham terhadap materi yang disampaikan serta memahami bagaimana menyelasaikan masalah tersebut secara matematis.

Disamping itu, antusiasme siswa terhadap media Schoology menunjukkan sikap yang positif, hal ini dapat ditunjukkan pada percakapan siswa dalam media Schoology seperti berikut:

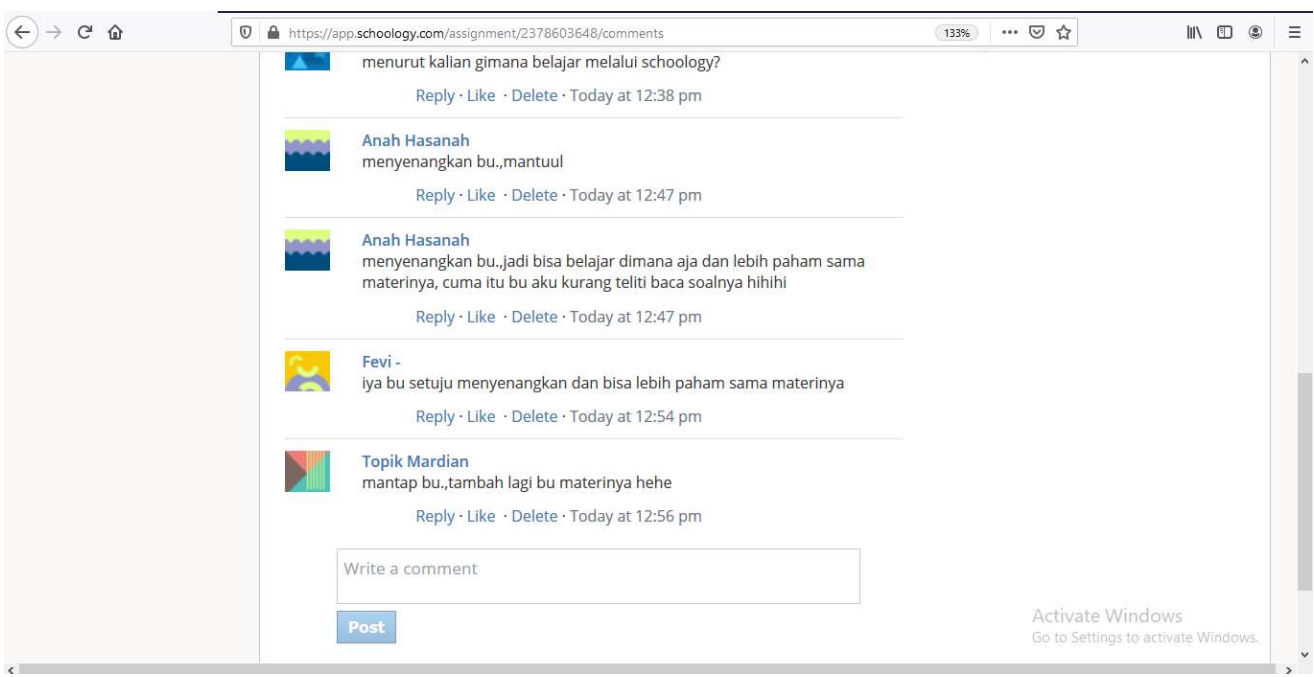

Gambar 3.3 Respon Siswa terhadap Media Schoology

Hal tersebut juga didukung dengan hasil penelitian-penelitian sebelumnya, diantaranya menurut Choirudin (2017) yang menyatakan bahwa Pembelajaran e-learning schoology berpengaruh positif terhadap hasil belajar siswa dan keaktifan siswa pada pembelajaran e-learning schoology berpengaruh positif terhadap hasil belajar. pembelajaran yang dilakukan dengan media Schoology memberikan pengaruh yang positif terhadap hasil belajar siswa. Hal tersebut dikarenakan siswa memahami materi yang diberikan dengan sangat baik, dengan kata lain media Schoology merupakan salah satu media pembelajaran e-learning yang tepat untuk siswa dalam memahami konsep materi yang diberikan, sehingga berpengaruh terhadap hasil belajar siswa.

\section{KESIMPULAN}

Berdasarkan hasil pembahasan diatas, maka penelitian yang dilakukan berkaitan dengan analisis kemampuan pemahaman konsep matematika siswa berbantuan media Schoology dapat disimpulkan bahwa:

a. Media pembelajaran e-learning Schoology dapat memberikan pemahaman konsep materi bangun ruang sisi datar kubus dan balok pada siswa kelas VIII yang berada 
di Lingkungan Desa Cihideunghilir Kecamatan Cidahu. Sehingga siswa dapat memecahkan masalah yang diberikan dengan baik.

b. Media Schoology dapat meningkatkan motivasi belajar siswa kelas VIII yang berada di Lingkungan Desa Cihideunghilir Kecamatan Cidahu.

c. Media Schoology dapat dijadikan sebagai alternatif pembelajaran secara daring baik dalam kondisi pandemi maupun kondisi normal.

\section{REFERENSI}

Aminoto, Tugiyo dan Pathoni, Hairul. 2014. Penerapan Media E-Learning Berbasis Schoology untuk Meningkatkan Aktivitas dan Hasil Belajar Materi Usaha dan Energi di Kelas XI SMA N 10 Kota Jambi. Jurnal Pendidikan Fisika. Jambi: Universitas Jambi.

Choirudin, choirudin. (2017). Efektivitas Pembelajaran Berbasis Schoology. NUMERICAL: Jurnal Matematika Dan Pendidikan Matematika, 1(2), 52-62. https://doi.org/10.25217/numerical.vli2.131

Karim, Asrul. 2011. Penerapan Metode Penemuan Terbimbing Dalam Pembelajaran Matematika untuk Meningkatkan Pemahaman Konsep dan Kemampuan Berpikir Kritis Siswa Sekolah Dasar. (Jurnal UPI) p.30 d akses pada tanggal 2 November 2015

Kesumawati, Nila. 2008. Pemahaman Konsep Matematik dalam Pembelajaran Matematika (Semnas Matematika dan Pendidikan Matematika 2008) di akses pada tanggal 2 Oktober 2015 dari http://core.ac.uk/download/pdf/11064532.pdf

K. Murni dan R. Harimurti. 2016. "Pengaruh E-learning berbasis Schoology terhadap Peningkatan Hasil Belajar Siswa dalam Materi Perangkat Keras Jaringan kelas X TKJ 2 pada SMK N 3 Buduran, Sidoarjo," ITedu, vol. 01, no. 01, pp. 86-90.

R. A. Sukamto dan M. Salahuddin. 2014. Rekayasa Perangkat Lunak Terstruktur dan Berorientasi Objek, Bandung: Informatika.

Sagala, Syaiful. 2003. Konsep dan Makna Pembelajaran untuk Membantu Memecahkan Problematika Belajar dan Mengajar. Bandung: Alfabeta

Siahaan, S. 2003. E-Learning (Pembelajaran Elektronik) Sebagai Salah Satu Alternatif Kegiatan Pembelajaran. Jurnal Pendidikan dan Kebudayaan. Bandung: Universitas Pasundan.

Stockley, Derek. 2006. E-Learning Definition and Explanation. Online. Diakses pada tanggal 30 Mei 2020 dari http://www.derekstockley.com.au/elearningdefinition.html.

Sugiyono. 2015. Metode Penelitian Pendidikan Pendekatan kuantitatif, Kualitatif, dan $R \& D$. Bandung: Alfabeta

Suharsimi Arikunto. 2011. Dasar-Dasar Evaluasi Pendidikan (Edisi Revisi), Jakarta: Bumi Aksara.

Sundayana, Rostina. 2014. Media Dan Alat Peraga Dalam Pembelajaran Matematika (Bandung: Alfabeta)

Widiantoro dan L. Rakhmawati. 2015. "Pengembangan Media Pembelajaran E-learning Berbasis Schoology pada Kompetensi Dasar Memahami Model Atom bahan SemiKonduktor di SMKN 1 Jetis Mojokerto.” JurnalPendidikan Teknik Elektro, vol. 04, no. 02, pp. 501-506. 